\title{
ANALISIS NUTRISI DODOL KELAPA
}

\author{
Yulianti \\ Dosen Teknologi Pangan Universitas Islam Indragiri
}

yulianti101@gmail.com

\begin{abstract}
Abstrak
Dodol merupakan makanan khas indonesia yang umunya terbuat dari tepung beras ketan dan gula serta berbagai bahan yang dapat ditambahakan demi peningkatan cita rasa, perbandingan yang tepat antara tepung beras ketan dan gula menjadi hal yang penting dalam pembuatan dodol kelapa, selain dapat mempengaruhi bentuk juga dapat mempengaruhi nilai kadar nutrisi didalamnya. Pada penelitian ini pembuatan dodol dilakukan dengan berbagai perlakuan dan penambahan bubur serta potongan kelapa, adapun perlakuan yang diterapkan adalah P1 (250 gram bubur daging buah kelapa $+30 \%$ tepung beras ketan $+40 \%$ gula putih), PII (250 gram bubur daging buah kelapa $+40 \%$ tepung beras ketan $+45 \%$ gula putih), PIII (250 gram bubur daging buah kelapa $+50 \%$ tepung beras ketan + $50 \%$ gula putih). Masing -masing perlakuan dilakukan analisis proksimat dengan masing-masing tiga kali ulangan, uji proksimat yang dilakukan diantaranya kadar air, kadar abu, kandungan lemak, protein dan karbohidrat. Kadar Air tertinggi terdapat pada perlakuan PI $(12,17 \%)$ dan terendah pada PIII $(10,47 \%)$, kadar abu tertinggi terdapat pada perlakan PIII $(0,6 \%)$ dan terendah pada PI $(0,4 \%)$, kandungan lemak tertinggi pada perlakuan PIII $(3,14 \%)$ dan terendah pada PI $(1,0 \%)$, kandungan protein tertinggi pada PIII $(1,7 \%)$ dan terendah pada PI $(1,5 \%)$ dan uji karbohidrat tertinggi terdapat pada perlakuan PIII $(80,05 \%)$ dan terendah pada PI $(72,31 \%)$. Hampir semua parameter uji yang dilakukan memberikan nilai yang hasilnya memenuhi standar, kecuali protein yang berada dibawah standar yang ditetapkan SNI.
\end{abstract}

Kata Kunci : analisis nutrisi, dodol kelapa, uji proksimat

\section{PENDAHULUAN}

Indonesia merupakan salah satu negara yang memiliki lahan tanaman kelapa terbesar di dunia dengan produksi 3,2 juta ton setara kopra. Lahan tanaman dan produksi tersebar diberbagai provinsi termasuk Riau kususnya Kabupaten Indragiri hilir.

Desa Sialang Panjang adalah salah satu desa yang ada di Kabupaten indragiri hilir yang sebagian besar lahannya ditanami pohon kelapa, kelapa yang ada masih dijual dalam bentuk kelapa bulat ataupun dalam bentuk kopra, meskipun kelapa tersebut dapat dimanfaatkan sebagai bahan pangan untuk memenuhi sumber gizi yang dibutuhkan manusia, sebagai bahan pangan kelapa dapat diolah menjadi berbagai produk makanan, salah satunya dodol kelapa.

Menurut Peraturan Pemerintah RI no 28 tahun 2004, pangan adalah sesuau yang berasal dari sumber hayati dan air baik yang diolah maupun tidak diolah untuk konsumsi manusia, pengembangan 
produk pangan menjadi hal yang pening salah satunya untuk menambah nilai ekonomi produk pangan tersebut (Lumba, 2012).

Pengolahan kelapa menjadi dodol diharapkan mampu membantu naiknya nilai ekonomi kelapa, dan khususnya dapat membantu ibu-ibu tim PKK Desa Sialang Panjang untuk meningkatkan nilai ekonomi Desa dan menciptakan makanan bergizi untuk pemenuhan gizi yang dibutuhkan masyarakat.

Dodol adalah panganan manis dari Indonesia yang bahan utamanya adalah santan kelapa, tepung ketan, gula pasir, gula merah dan garam, dan dapat diberikan bahan tambahan yang dapat menciptakan cita rasa dodol yang dihasilkan. Meskipun santan kelapa merupakan bahan utama pembuatan dodol namun daging kelapa juga dapat menjadi bahan tambahan. Kelapa memiliki gizi yang tinggi, mengandung asam lemak esensial dan asam amino esensial yang diperlukan oleh tubuh (Rindengan et al, 2002).

\section{METODOLOGI}

Penelitian

dilakukan di Laboratorium Teknologi Pangan, Fakultas Pertanian, Universitas Islam indragiri dan Laboratorium Teknologi Pertanian Universitas Andalas. Peralatan yang digunakan: blender, timbangan analitik, kertas minyak/plastik, kompor, pengaduk kayu/spatula, pisau, sendok, talenan, wajan dan wadah. Bahan yang digunakan: Daging buah kelapa segar yang digunakan diambil dari kelapa (Cocos nucifera) Desa Sialang Panjang, Kec Tembilahan Hulu, Indragiri Hilir, Riau dengan tingkatan umur setengah tua, tepung beras ketan putih (rose brand), gula putih, santan, air, pewarna pandan alami.

Tahap pertama yaitu mengupas kulit kelapa setengah matang dan diambil dagingnya, dipotong-potong membentuk dadu dan dibersihkan, ini digunakan sebagai bahan tambahan pada pembuatan dodol. Adapun prosedur pembuatan dodol dapat dilihat pada Gambar 1 dan dodol dibuat dengan berbagai perlakuan (Gambar 2). Dodol yang dihasilkan dilakukan analisis proksimat untuk melihat kadar protein, lemak, air, abu dan karbohidrat.

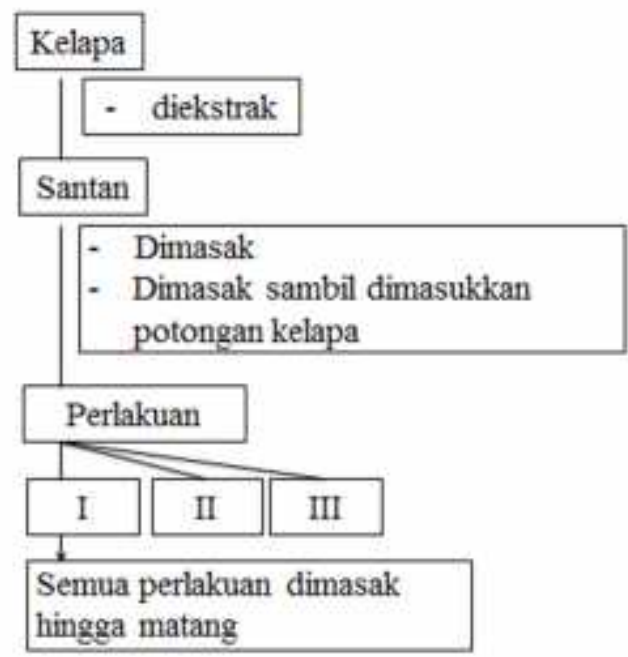

Gambar 1. Prosedur Pembuatan Dodol Kelapa 
PI: 250 gram bubur daging buah kelapa $+30 \%$ tepung beras ketan $+40 \%$ gula putih PII: 250 gram bubur daging buah kelapa $+40 \%$ tepung beras ketan $+45 \%$ gula putih PIII: 250 gram bubur daging buah kelapa $+50 \%$ tepung beras ketan $+50 \%$ gula putih

Gambar 2. Berbagai Perlakuan pada Pembuatan Dodol Kelapa

\section{HASIL DAN PEMBAHASAN}

\section{Kadar Air}

Air merupakan salah satu unsur penting dalam bahan pangan. Uji kadar air dilakukan untuk mengetahui jumlah air yang terkandung dalam dodol yang ditambahkan bubur dan potongan kelapa, kadar air $(20 \%)$ dalam suatu bahan pangan sangat penting karena akan mempengaruhi daya simpan pangan tersebut (Syarief et al., 1988). Meskipun kadar air tidak bisa dijadikan parameter absolut untuk meramalkan kecepatan terjadinya kerusakan bahan makanan. Nilai kadar air dalam dodol kelapa pada berbagai perlakuan dapat dilihat pada Gambar 3.

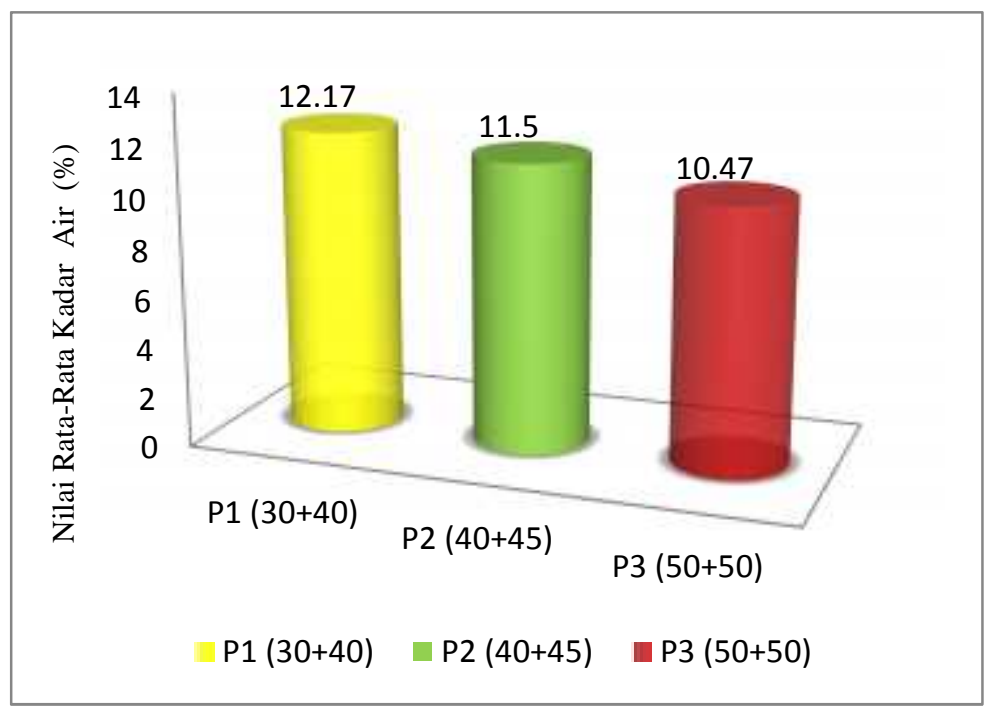

Gambar 3. Nilai Rata-Rata Kadar Air Dodol Kelapa

Dari Gambar 3 dapat dilihat bahwa kadar air dodol kelapa dengan berbagai perlakuan menunjukkan hasil yang berbeda-beda, meskipun nilai perbedaan tersebut tidak terlalu jauh. Kadar air untuk perlakuan PI yaitu $10,47 \%$, dan pada perlakuan PII berjumlah $11,5 \%$, sementara perlakuan PIII memberikan nilai kadar air $12,17 \%$. Terlihat bahwa nilai kadar air meningkat seiring menurunnya jumlah tepung beras yang digunakan dan meningkatnya jumlah gula yang digunakan. Semakin tinggi kadar amilopektin dari bahan makanan maka kemampan mengikat air akan semakin meningkat (Siswoputranto, 1989). Namun demikian adanya gula pada bahan pangan juga mempengaruhi daya mengikat air.

\section{Kadar Abu}

Uji kadar abu dilakukan untuk mengetahui kandungan total abu pada dodol yang diberi penambahan bubur dan potongan kelapa pada berbagai 
konsentrasi tepung beras ketan dan gula setiap perlakuan dapat dilihat pada yang berbeda, nilai kadar abu untuk Gambar 4 .

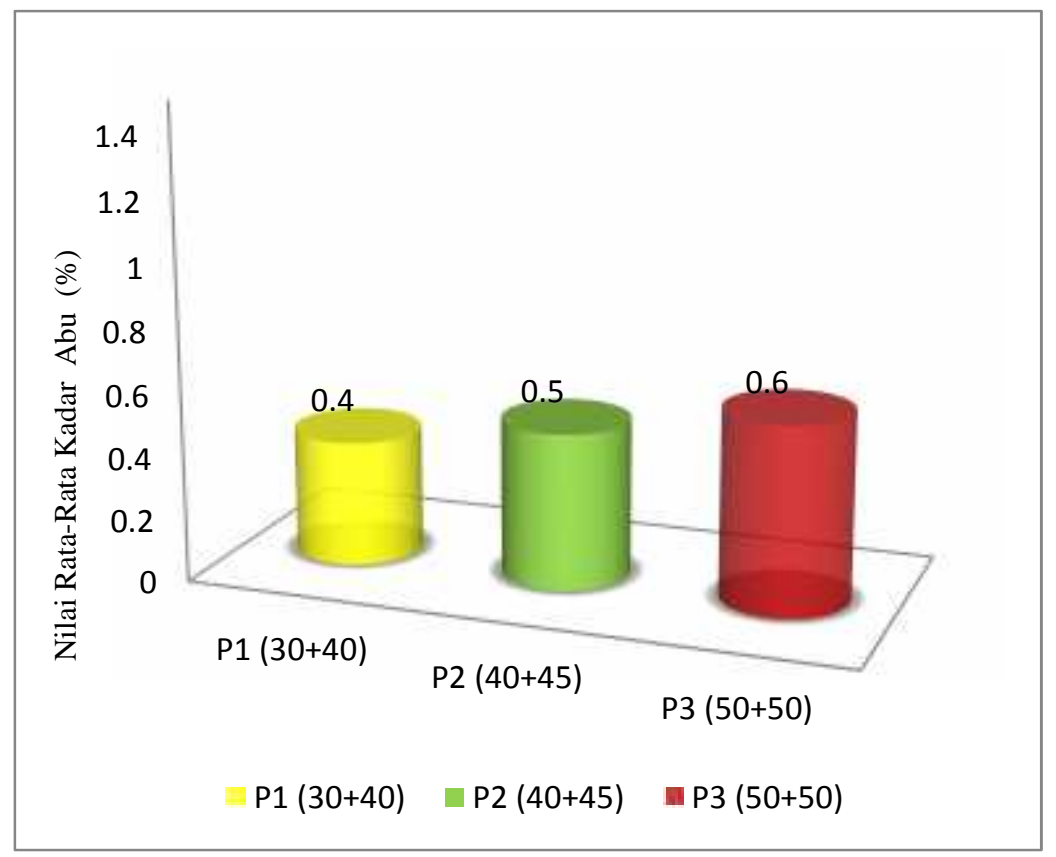

Gambar 4. Nilai Rata-Rata Kadar Abu Dodol Kelapa

Dari hasil pada Gambar 4 dapat dilihat bahwa nilai kadar abu berbeda beda seiring dengan perbedaan jumlah konsentrasi beras ketan dan gula, meskipun perbedaan tersebut tidak jauh berbeda, kadar abu meningkat seiring peningkatan konsentrasi beras ketan, dimana pada $\mathrm{P} 1$ kadar abu $0,4 \%$, pada P2 kadar abu 0,5\% dan pada P3 kadar abu $0,6 \%$. Adanya nilai perbedaan tersebut disebabkan karena perbedaan konsentrasi beras ketan yang digunakan. Perbedaan nilai yang dihasilkan dari semua perlakuan masih berada dalam ambang batas dodol, dimana syarat mutu dodol sesuai SNI N 01-2986-1992 nilai maksimal abu dodol yaitu 1,5\%.

\section{Kadar Lemak}

Adanya lemak pada bahan pangan dapt memberi rasa guruh dan menciptakan tekstur yang lunak dan mudah ditelan, hasil uji kadar lemak dapat dilihat pada Gambar 5.

Pada Gambar 5 terlihat bahwa kadar lemak berkisar dari 1 sampai dengan 3,14. Kadar lemak tertinggi terdapat pada perlakuan P3 yaitu penambahan beras ketan dan gula dengan perbandingan yang sama, yang berarti semakin banyak jumlah tepung beras yang digunakan maka semakin tinggi kadar lemak yang dihasilkan. Menurut SNI kadar minimal lemak pada dodol yaitu 3\%, maka dodol klapa pada perlakuan P3 memenuhi syarat SNI. Meskipun, kadar lemak yang sangat tinggi pada dodol dapat mempercepat proses ketengikan. Hardiansyah mengatakan bahwa lemak terdapat dalam setiap bahan pangan dan mempengaruhi proses ketengikan (Hardiansyah, 2000). 


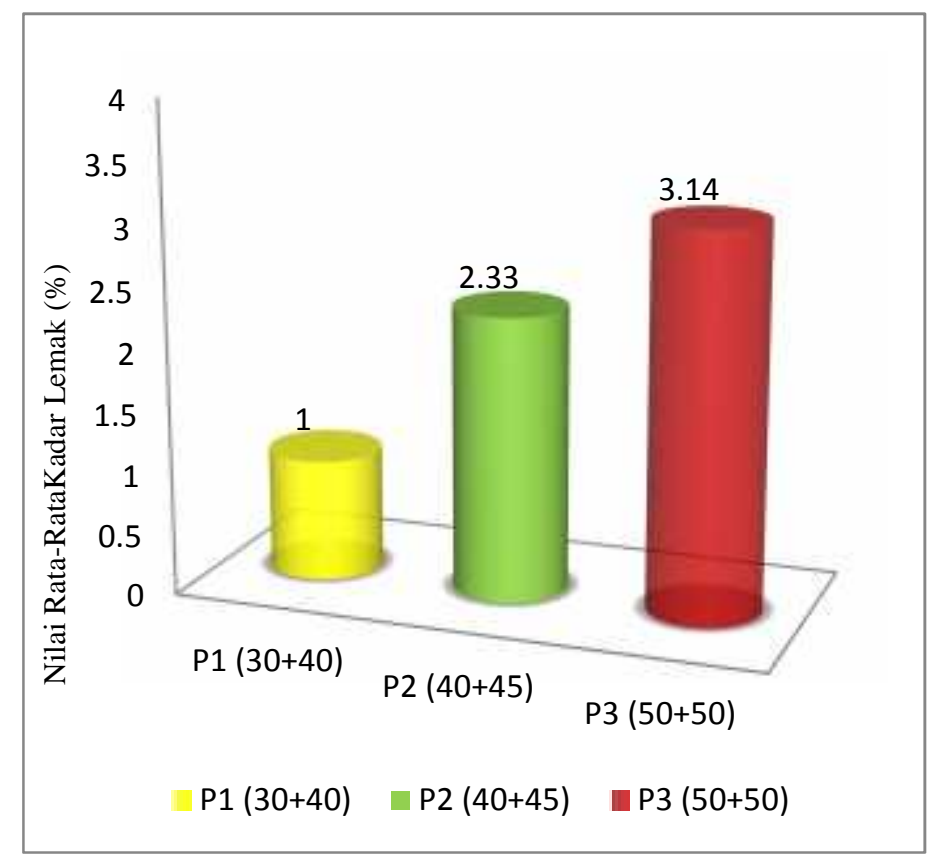

Gambar 5. Nilai Rata-Rata Kadar Lemak Dodol Kelapa

Pada Gambar 5 terlihat bahwa kadar lemak berkisar dari 1 sampai dengan 3,14. Kadar lemak tertinggi terdapat pada perlakuan P3 yaitu penambahan beras ketan dan gula dengan perbandingan yang sama, yang berarti semakin banyak jumlah tepung beras yang digunakan maka semakin tinggi kadar lemak yang dihasilkan. Menurut SNI kadar minimal lemak pada dodol yaitu 3\%, maka dodol klapa pada perlakuan P3 memenuhi syarat SNI. Meskipun, kadar lemak yang sangat tinggi pada dodol dapat mempercepat proses ketengikan. Hardiansyah mengatakan bahwa lemak terdapat dalam setiap bahan pangan dan mempengaruhi proses ketengikan (Hardiansyah, 2000).

\section{Kadar Protein}

Kandungan protein pada dodol menjadikan dodol sebagai makanan yang penting untuk dikonsumsi, kandungan protein pada dodol kelapa dengan berbagai perlakuan terhadap tepung beras ketan dan gula dapat dilihat pada Gambar 6.

Dari gambar diatas dapat dilihat bahwa nilai kadar protein dari dodol kelapa yang diberi perlakuan berbeda berkisar 1,5 sampai 1,7. Nilai kadar protein tertinggi didapatkan pada perlakuan P3, perbedaan protein sudah jelas berasal dari perbedaan jumlah tepung beras ketan yang digunakan. Meskipun semua nilai kadar protein tersebut masih dibawah ambang batas kadar minimal dodol yaitu $3 \%$, sesuai yang dituliskan pada bahwa menurut SNI kadar minimal protein dodol adalah sebesar 3\%. Rendahnya kadar protein pada dodol kelapa dapat disebabkan oleh suhu yang digunakan pada saay pengolahan yang menyebabkan denaturasi protein. Menurut Matias, protein pangan terdenaturasi jika dipanaskan pada suhu moderat $60-90^{\circ} \mathrm{C}$ selama satu jam atau lebih (Matias, 2010). 


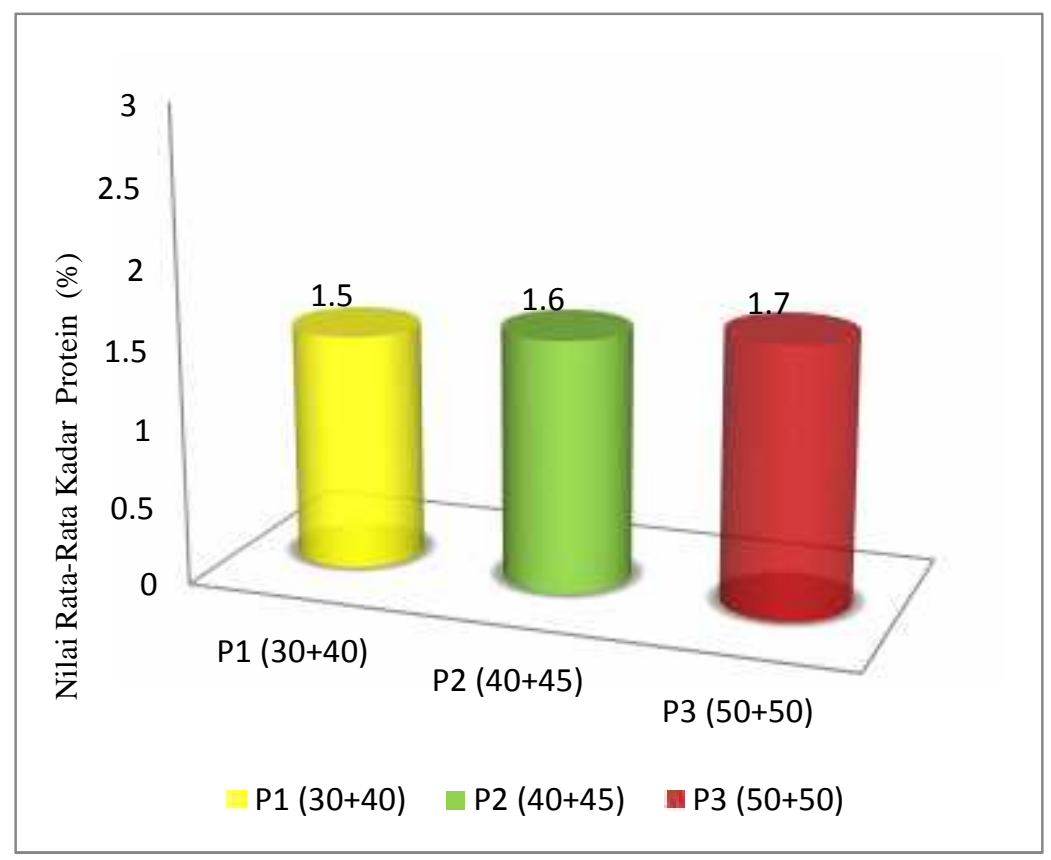

Gambar 6. Nilai Rata-Rata Kadar Protein Dodol Kelapa

Kadar Karbohidrat

Karbohidrat terdapat dalam jumlah yang cukup tinggi pada bahan pangan sehingga dapat dignakan sebagai bahan pokok manusia, kandungan karbohidrat pada dodol kelapa dapat dilihat pada Gambar 7.

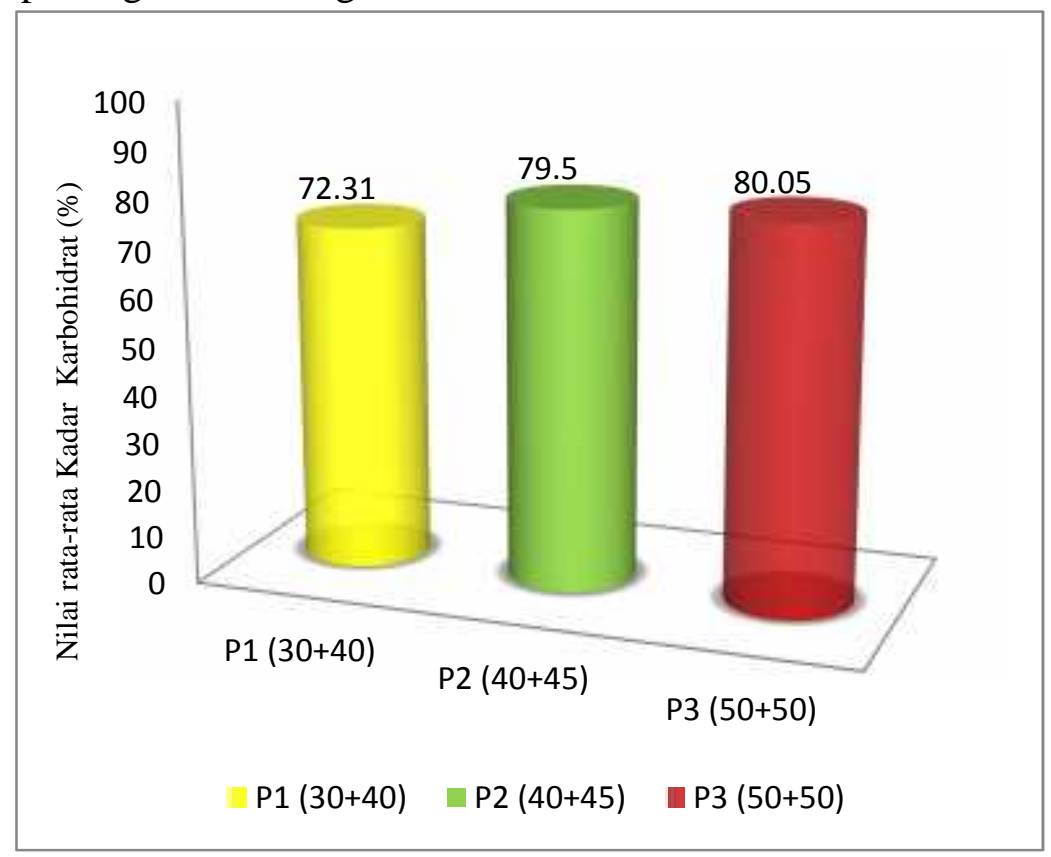

Gambar 7. Nilai Rata-Rata Kadar Karbohidrat Dodol Kelapa 
Pada Gambar 7 dapat dilihat nilai karbohidrat yang didapatkan berbedabeda, nilai tertinggi terdapat pada perlakuan P3 yaitu $80,05 \%$ dan terendah pada perlakuan P1 yaitu $72,31 \%$. Tingginya kadar karbohidrat pada perlakuan P3 dapat disebabkan kandungan karbohidrat yang tinggi pada beras ketan. Karbohidrat dalam tepung beras terdapat sebagai amilosa dan amilopektin, karbohidrat berfungsi sebagaiprotein sparer, dimana jika karbohidrat yang ada cukup untuk keperluan energi maka protein digunakan sebagai fungsi utamanya yaitu zat pembangun (Tejasari, 2005).

\section{KESIMPULAN}

1. Terdapat perbedaan nilai uji proksimat terhadap dodol kelapa yang dibuat dengan bebagai perlakuan dimana perbeaan perlakuan terhadap perbandingan konsentrasi beras ketan dan gula yang digunakan.

2. Nilai kadar air berkisar 10,47 sampai 12,17, kadar Abu berkisar 0,4 sampai 0,6, kadar Lemak berkisar 1 sampai 3,14, kadar protein 1,5 sampai 1,7 dan nilai kadar karbohidrat berkisar 72,31 sampai 80,05.

3. Hampir semua parameter uji yang dilakukan memenuhi standar minimal pada dodol, kecuali protein yang berada dibawah standar yang ditetapkan SNI.

\section{DAFTAR PUSTAKA}

Hardiansyah. 2000. Pengendalian Mutu dan Keamanan Pangan. Pergizi Pangan Indonesia. PAPTI, IPB dan Proyek CHN-3, direktorat jenderal pendidikan tinggi, Jakarta.

Lumba, R. 2012. Kajian Pembuatan Beras Analog Berbasis Tepung Umbi Daluga (Crytosperma merkusii (Hassk) Schott). Jurnal Universitas Samratulangi, 5(1), 113.

Matias, V. 2010. Denaturasi Protein. Makalah. Fakultas Teknologi Industri Pertanian Universitas Sahid. Jakarta.

Rindengan, B. 2002. Kandungan Asam Lemak Omega 9 dan Omega 6 pada Beberapa Jenis Kelapa Hibrida. Buletin Palma 28: 1-6.

Siswoputranto, L.D. 1989. Teknologi Pasca Panen Kentang. Liberty. Yogyakarta.

Syarief, R., \& A. Irawati. 1988. Pengetahuan Bahan untuk Industri Pertanian. PTMediyatama Sarana Perkasa. Jakarta.

Tejasari. 2005. Nilai Gizi Pangan. Yogyakarta : Graha Ilmu. 